\begin{tabular}{|c|c|c|}
\hline & KEMAS 16 (2) (2020) 296-307 & OREMAS \\
\hline & Jurnal Kesehatan Masyarakat & 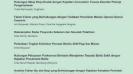 \\
\hline & http://journal.unnes.ac.id/nju/index.php/kemas & $=-m=$ \\
\hline
\end{tabular}

\title{
Breastfeeding Patterns as a Determinant of Fertility in the Province of East Nusa Tenggara, Indonesia
}

\author{
Wahyu Utomo ${ }^{\bowtie}$, Robani Catursaptani, Dian Kristiani Irawaty, Muhammad Dawam, Mugia \\ Bayu Rahardja
}

Badan Kependudukan dan Keluarga Berencana Nasional (BKKBN), Indonesia

\begin{tabular}{l} 
Article Info \\
\hline Article History: \\
Submitted September 2020 \\
Accepted November 2020 \\
Published November 2020 \\
\hline Keywords: \\
Fertility \\
decomposition, \\
breastfeeding, East \\
Nusa Tenggara, IDHS. \\
\hline DOI \\
https://doi.org/10.15294/ \\
kemas.v16i2.26136
\end{tabular}

\begin{abstract}
Eventhough the fertility level in East Nusa Tenggara had decrease slightly during the last 10 years' period, the fertility level in the area had still considered much higher than other provinces in Indonesia. However, the infertility index of breastfeeding in the Province had been the lowest in Indonesia, which revealed the breastfeeding duration in East Nusa Tenggara was the longest period in Indonesia. This study aimed to identify the association between maternal characteristics and breastfeeding behavior in East Nusa Tenggara Province in 2017. This study analized women who had children based on the 2017 Indonesian Demographic and Health Survey (IDHS). The analysis used in this study includes univariable, bivariable, logistic regression analysis. After controlling for maternal characteristics variables, age, education and work status of the mother were found as the most contributed factors to breastfeeding behavior in East Nusa Tenggara Province in 2017.
\end{abstract}

\section{Introduction}

NTT Province is ranked 33 nationally with an HDI value of 63.73 in 2017. The number of poor people in NTT is 1.13 million people with a poverty line of IDR 343,396 per capita per month. NTT is an archipelago province in eastern Indonesia which consists of the five large islands of Flores, Sumba, Timor, Alor and Lembata. The land area of NTT is $47,931.54$ $\mathrm{km}^{2}$, most of the area is mountainous and hilly (BPS, 2018).

The birth rate in East Nusa Tenggara (NTT) is always the highest among other provinces, except in the 2012 IDHS results where this province is in 4 th place after Papua, West Papua, and West Sulawesi Provinces. Marriage rates, contraceptive use, intentional abortion, and breastfeeding are the most important immediate variables and have a direct effect on reducing fertility because together they account for nearly $96 \%$ of the variation in fertility in a population (Bongaarts and Potter, 1983). The use and effectiveness of contraceptives are the main factors affecting the decline in fertility rates in Indonesia, compared to other factors, namely the pattern of marriage and breastfeeding behavior. The infertility index while breastfeeding in NTT is the best at the national level. This province has the lowest infertility index during breastfeeding among other provinces (Samosir, 2019). Breastfeeding has the effect of inhibiting ovulation and extending the birth interval, which in turn has an impact on decreasing natural fertility.

The factor of contraceptive use in NTT Province ranks the fourth lowest after Papua, West Papua and Maluku Provinces. The marriage pattern factor shows that NTT Province has the proportion of being married $\left(\mathrm{C}_{\mathrm{m}}>0.6\right)$, which means that women of childbearing age in this province spend a relatively long time in the status of marriage (Samosir, 2019). 
In a study in NTT Province, there is a local culture that encourages couples to have children with the same full sex and number and is commonly referred to as 'belis' (Rahmadewi and Asih, 2011). The age at first marriage of women affects fertility because the younger the age at first marriage, the longer the woman's life is spent in marriage and the risk of having children (Bongaarts and Potter, 1983). A study in West Sumatra found that knowledge, employment status, husband's support and the role of health workers had a significant effect on the application of the lactational amenorrhoea method (MAL) (Rifdi, F. \& Martika, 2019). A study in East Java stated that there was a relationship between exclusive breastfeeding and the return of menstruation as much as $75 \%$, respondents who were not exclusively breastfed by returning to rapid menstruation were $29.2 \%$ (Muzayyaroh and Fatimah, 2012). Nursing patterns vary in Indonesia because they are related to the behavior of mothers, families and communities in following the modernization process (Wilopo, 2009).

Based on the results of previous studies above, the high fertility rate that occurs is of course not only caused by factors of marriage, use of contraceptives, deliberate abortion, and breastfeeding (Harrison, 2016; Glasier, 2019). Demographic, social, economic, and cultural factors affect fertility through proximate determinants that directly affect fertility rates (Davis and Blake, 1956; Oyekale, 2018). Therefore, it is important to carry out further analysis of trends or patterns of changes in determinants of fertility using data from the 2002/2003 and 2017 IDHS results in NTT Province, so as to get a picture of taking a more appropriate approach in reducing the fertility rate in this province. The purpose of this study was to determine the proximate determinants of the breastfeeding index using the fertility decomposition based on the 2002/2003 IDHS and 2017 IDHS results.

\section{Method}

This study uses quantitative research methods with a secondary data analysis approach. The data used in this study are sourced from the 2002/2003 and 2017 IDHS data.The selection of the 2002/2003 and 2017 IDHS data refers to the TFR in Indonesia which began to experience fertility stalling for a period of 10 years from the 2002/2003 IDHS to the IDHS 2012, namely stagnating at 2.6 children per woman and experiencing a decline in 2017. The unit of analysis in this study was women aged 15-49 years who live in East Nusa Tenggara Province. Data analysis was performed using the fertility decomposition formula to determine the marriage index $(\mathrm{Cm})$, the non-contraceptive index $(\mathrm{Cc})$, and the infertility index during breastfeeding $(\mathrm{Ci})$ (Bongaarts, 1978).

Breastfeeding has the effect of inhibiting ovulation, thereby extending the birth interval and reducing natural fertility (Bouchard, 2018; Lim, 2019). Quantitative estimation of the effect of reducing fertility from infertility during breastfeeding can be estimated by comparing the mean birth interval without and with breastfeeding (Samosir, 2019). The birth interval can be divided into four components. The first component is an infertile interval immediately after delivery. The second component is the waiting time for conception, which begins at ovulation after delivery and ends with a conception. The third component is the time added by accidental fetal death, a mean of two months per birth interval. The fourth component is the period of pregnancy for nine months (Samosir, 2019)

Furthermore, a univariate analysis was also conducted to see the percent distribution of WUS respondents who were breastfeeding as an intermediate determinant. Bivariate analysis was performed to see the percent distribution between the independent variables (age, education, place of residence and wealth quintile) and the dependent variable (breastfeeding) and at the same time to see the correlation between the two variables. Data analysis used the stata version 20.0 software systems by providing treatment to the data set in order to obtain weighted population estimates.

\section{Results and Discussion}

Figure 1. shows that the results of the 2002/2003 IDHS, the overall fertility rate (TFR) of East Nusa Tenggara is 4.10 children per woman. Meanwhile, the results of the 2017 SDKI East Nusa Tenggara TFR were 3.37 children per woman. From the two IDHS results, it means that there was a decrease in the TFR of 


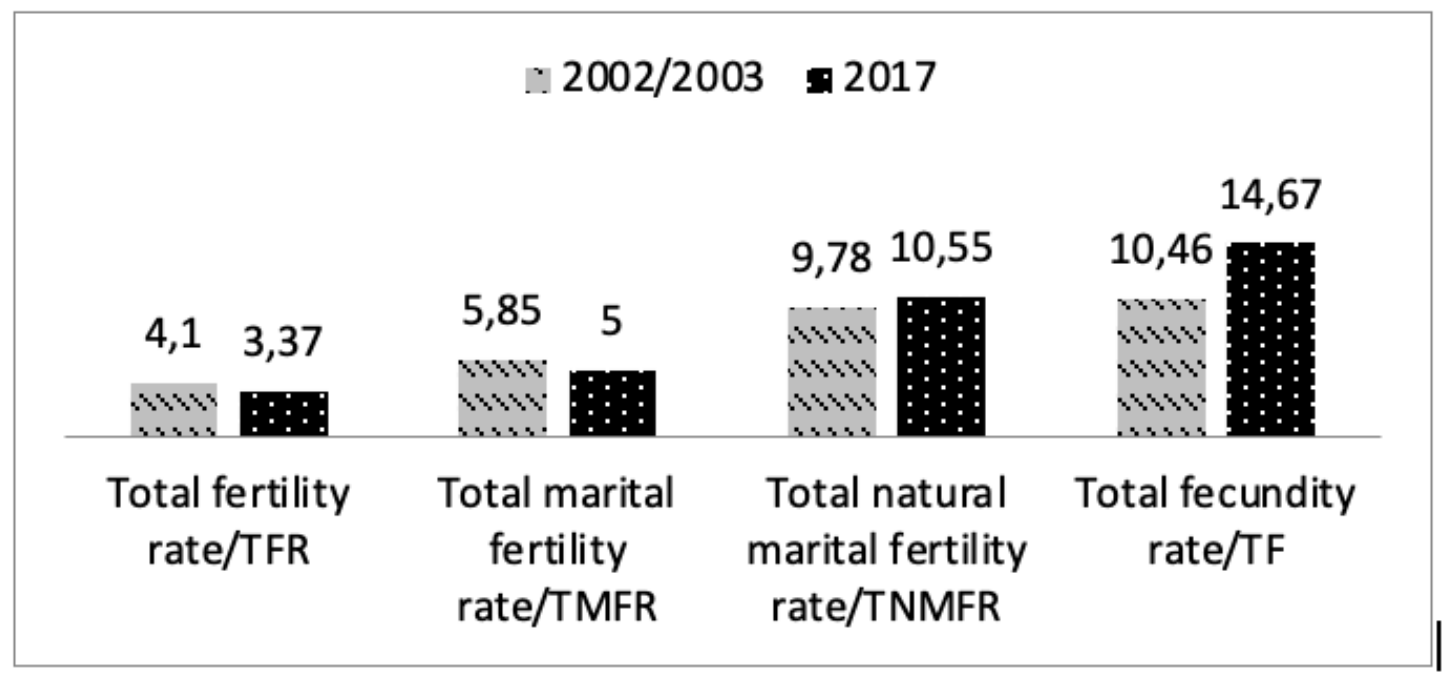

Figure 1. The results of comparison of the fertility decomposition variables for the 2002-03 and 2017 IDHS in NTT

around 0.73 births per woman from 2002/2003 to 2017. Although the overall fertility rate has decreased, the results of the IDHS in these two periods show that NTT has always been in one of the provinces with the highest TFR position at the national level. The 2002/03 IDHS results also show that a TFR of 4.10 children per woman resulted in TMFR, TNMFR, and TF of 5.85, 9.78 and 10.46, respectively. Meanwhile, the 2017 IDHS with a TFR of 3.37 resulted in TMFR of 5.00, TNMFR of 10.55 and a TF of 14.67 children per woman.

In Figure 1, the changes in fertility measures (TFR, TMFR, TNMFR, and TF) in NTT between 2002/03 and 2017. Data from the 2002/03 IDHS, found that the index of proportion of marriage $\left(\mathrm{C}_{\mathrm{m}}\right)$, noncontraception $\left(\mathrm{C}_{\mathrm{c}}\right)$, and infertility during breastfeeding $\left(\mathrm{C}_{\mathrm{i}}\right)$ in NTT were $0.70,0.60$, and 0.93 , respectively. Meanwhile, the results of the 2017 IDHS were the proportion of marriage $\left(\mathrm{C}_{\mathrm{m}}\right)$ 0.67, non-contraception $\left(\mathrm{C}_{\mathrm{c}}\right) 0.47$, and infertility during breastfeeding $\left(C_{i}\right) 0.72$. Thus, between 2002/03 and 2017, in NTT, the index of the proportion of marriage $\left(\mathrm{C}_{\mathrm{m}}\right)$ and infertility during breastfeeding $\left(\mathrm{C}_{\mathrm{i}}\right)$, the index of noncontraception $\left(\mathrm{C}_{\mathrm{c}}\right)$, decreased. This means that the effect of limiting fertility from marital patterns, infertility during breastfeeding and the use and effectiveness of contraceptives has increased respectively.
The fecundity rate (TF) in NTT in $2002 / 03$ was 10.5 children per married woman with a TFR value of 4.1 children per married woman. While NTT's TFR value in 2017 increased higher than the previous one, namely 14.67 children per married woman, the final result of the TFR value was actually lower, namely 3.37 children per married woman. By decreasing the TFR value in NTT to 3.37 children per married woman, it reduces the range of achievement to the National TFR value of 2.42. The pattern of each marriage index $\left(\mathrm{C}_{\mathrm{m}}\right)$, non-contraceptive index $\left(\mathrm{C}_{\mathrm{c}}\right)$, and infertility index during breastfeeding $\left(\mathrm{C}_{\mathrm{i}}\right)$ influenced the increase and decrease in TF value up to the TFR value.

From Figure 2. It can be seen that the non-contraceptive index $\left(\mathrm{C}_{\mathrm{c}}\right)$ value has the most dominant relative influence in NTT in 2002/03 amounting to $61.8 \%$ and 2017 influencing 49.1\%. Meanwhile, the relative effect on the marriage index $\left(\mathrm{C}_{\mathrm{m}}\right)$ was $27.5 \%$ and $14.4 \%$ and the infertility index during breastfeeding $\left(\mathrm{C}_{\mathrm{i}}\right)$ was $10.7 \%$ and $36.5 \%$. There was a decrease in the relative effect of the contraceptive index $\left(\mathrm{C}_{\mathrm{c}}\right)$ and the marriage index of around $12 \%$ to $13 \%$, while the infertility index during breastfeeding $\left(C_{i}\right)$ actually experienced a quite high increase of effect, namely $26 \%$. In addition, after 15 years there was a significant increase in the median infertility during breastfeeding (i), from 2.9 months to 9.3 months. 


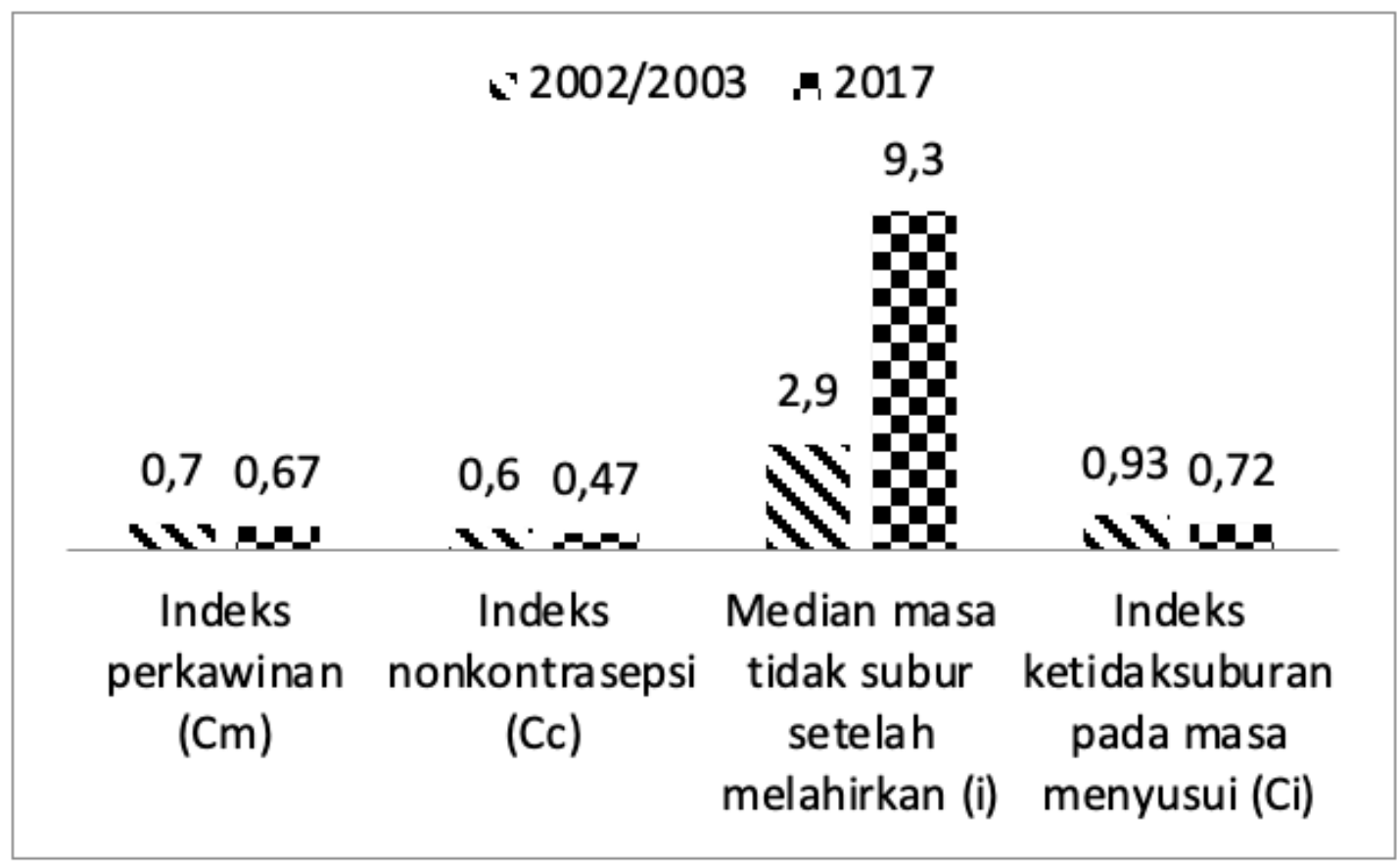

Figure 2. Comparison of the 2002-03 and 2017 IDHS fertility decomposition indexes in NTT

The NTT marriage index according to the $2002 / 2003$ IDHS data is 0.70 and the 2017 IDHS is 0.67 . This means that women of childbearing age in NTT in 2002-2003 spent $70 \%$ and $67 \%$ in 2017 of their reproductive period in the married status which exposed them to childbearing. This shows that the marriage pattern was able to reduce fertility by $70 \%$ in $2002-2003$ and $67 \%$ in 2017 . In addition, the marriage index in NTT province has increased by 0.03 against the TFR.

The non-contraceptive index $\left(\mathrm{C}_{c}\right)$ in NTT was 0.60 in 2002-2003 and 0.47 in 2017. This means that the fertility rate in marriage (TMFR) in NTT was, respectively, 60\% and $47 \%$ lower than that of TNMFR. So, in 20022003 the contraceptive pattern (prevalence and effectiveness of contraception) had an effect on reducing fertility (fertility-reducing effect) in NTT, which was $60 \%$ and $47 \%$ in 2017 . In addition, it can also be interpreted that women of reproductive age who are married and are not sterile protected by effective contraception by $40 \%$ in $2002 / 3$ and $53 \%$ in 2017 . There was an increase in the effect of using effective contraception by $13 \%$ over a period of 15 years.

In 2002-03 the value of the infertility index during breastfeeding $\left(\mathrm{C}_{\mathrm{i}}\right)$ NTT was
0.93 and in 2017 it was 0.72 . This means that the natural fertility rates (TNMFR) are $93 \%$ and $72 \%$ lower than the natural fertility rates without breastfeeding (TF), respectively. Thus, the pattern of breastfeeding in NTT has the effect of limiting fertility (fertility-limiting) by $93 \%$ and $72 \%$, respectively. There is a decrease in the $\mathrm{Ci}$ value of 0.21 , or it can be interpreted that the effect of the infertility index during breastfeeding has increased. Meanwhile, the median of infertility during breastfeeding in NTT also increased from 2.9 months to 9.3 months. The longer the median infertility during breastfeeding, the smaller the infertility index value during breastfeeding.

The analysis of changes in fertility measures between 2002/03 and 2017 shows that the difference between the overall fertility rate (TFR) and the fertility rate in marriage (TMFR) decreased from 1.75 births according to the 2002/03 IDHS to 1.63 births according to the IDHS 2017. Meanwhile, the difference between the fertility rate in marriage (TMFR) and the natural fertility rate (fertility rate in marriages without contraception and deliberate abortion / TNMFR) increased from 3.93 births according to the 2002-03 IDHS to 5.55 births according to the IDHS 2017. 


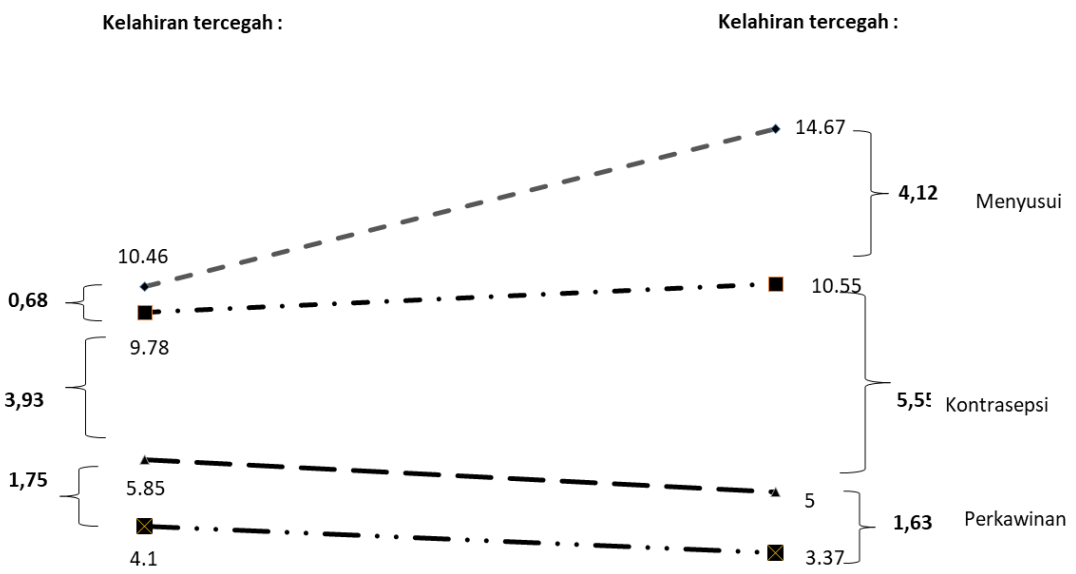

SDKI $2002 / 3$

SDKI 2017

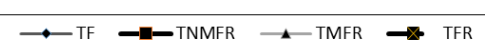

Figure 3. Change in fertility measures: NTT 2002/03 and 2017

Furthermore, the difference between the natural fertility rate (TNMFR) and the natural fertility rate without breastfeeding (TF) increased from 0.68 births according to the 2002/03 IDHS to 4.12 births according to the 2017 IDHS, meaning that according to the 2002/03 IDHS results, the pattern of marriages resulted in prevented births were as much as TMFR - TFR $=5.85-4.10=1.75$ births per woman. Meanwhile, the pattern of marriage and the use and effectiveness of contraception resulted in preventable births as much as TNMFR - TMFR $=9.78-5.85=3.93$ births per married woman. Furthermore, the pattern of marriage, use and effectiveness of contraception, and breastfeeding resulted in preventable births of TF - TNMFR $=10.46-$ $9.78=0.68$ births per married woman.

According to the results of the 2017 IDHS, the pattern of marriage resulted in prevented births as much as TMFR - TFR $=5.00-3.37=$ 1.63 births per woman. Meanwhile, the pattern of marriage and the use and effectiveness of contraception resulted in prevented births of
TNMFR - TMFR $=10.55-5.00=5.55$ births per married woman. Furthermore, the pattern of marriage, contraceptive use and effectiveness, and breastfeeding resulted in prevented births of TF - TNMFR $=14.67-10.55=4.12$ births per married woman.

The results of further analysis of the fertility decomposition of the 2017 Indonesian Demographic and Health Survey (IDHS), the most dominant pattern is about the contraceptive index (Samosir, 2019). Compared to 33 other provinces, the components of breastfeeding in Indonesia from the 2017 IDHS found that breastfeeding as a proxy for infertility towards fertility was strong or dominant in the province of East Nusa Tenggara compared to 33 other provinces ( $\mathrm{Ci}$ index 0.72 ). For women with children under 2 years, the determinants of amenorrhoea (no menstruation) after giving birth are one of them because exclusive breastfeeding, so that exclusive breastfeeding is associated with post partum amenorrhoea (Afifi, 2008).

Based on table 1, $92.1 \%$ of mothers aged 
Table 1. Percent distribution of maternal characteristics variables with breastfeeding variable, East Nusa Tenggara, 2017

\begin{tabular}{|c|c|c|}
\hline \multirow{3}{*}{ Variable } & \multicolumn{2}{|c|}{ Breastfeeding } \\
\hline & $\leq 6$ Months & $>6$ Months \\
\hline & $\%$ & $\%$ \\
\hline \multicolumn{3}{|l|}{ Ages } \\
\hline $30-49$ & 92.1 & 7.9 \\
\hline $15-29$ & 79.1 & 20.9 \\
\hline \multicolumn{3}{|l|}{ Residence } \\
\hline City & 87.9 & 12.1 \\
\hline Village & 88.9 & 11.1 \\
\hline \multicolumn{3}{|l|}{ Education } \\
\hline No School, Elementary School, Junior High School & 89.7 & 10.3 \\
\hline High School + & 80.3 & 19.7 \\
\hline \multicolumn{3}{|l|}{ Wealth Quintile } \\
\hline Middle above and Top, & 85.2 & 14.8 \\
\hline Lowest, Lower and Medium & 88.9 & 11.1 \\
\hline Intermediate & & \\
\hline \multicolumn{3}{|l|}{ Work Status } \\
\hline $\begin{array}{l}\text { Not working } \\
\text { Working }\end{array}$ & 93.4 & 6.6 \\
\hline \multicolumn{3}{|l|}{ Place of Birth } \\
\hline Medical facility & 89.6 & 10.4 \\
\hline Not a Medical Facility & 84.5 & 15.5 \\
\hline \multicolumn{3}{|l|}{ Childbirth Helper } \\
\hline Not a Health Officer & $\begin{array}{l}80.4 \\
81.8\end{array}$ & 19.6 \\
\hline Health Officer & 81.8 & 18.2 \\
\hline
\end{tabular}

30-49 years who provide breastfeeding with a duration of 0-6 months, while those aged 1529 are $79.1 \%$. This suggests that more mothers who breastfeed children with duration of 0-6 months are those aged 30-49 years.

Based on the area of residence, it shows that mothers who live in rural areas have a greater proportion of breastfeeding practices with a duration of $0-6$ months, namely $88.9 \%$ compared to mothers living in urban areas, $87.9 \%$. Furthermore, the proportion of mothers who provide breastfeeding with a duration of 0-6 months is greater for those who do not go to school, SD and SMP by $89.7 \%$ compared to mothers who have graduated from high school and college, $80.3 \%$. Based on the wealth quintile, the highest proportion of mothers who provide breastfeeding with a duration of 0-6 months are those who have the lowest, middle and middle quintile, reaching $88.9 \%$. The results showed that $93.4 \%$ of mothers with working status, while $80.0 \%$ of mothers who did not work or only became housewives, gave breast milk for 0-6 months. The place of delivery is a place of health care chosen by the mother to give birth to a child.

From table 1 it can also be seen that the mothers who chose to give birth in health facilities were $89.6 \%$, while $84.5 \%$ were not in health facilities. Furthermore, based on birth attendants, $81.8 \%$ of mothers who were assisted in delivery by health workers provided breast milk with duration of 0-6 months. Meanwhile, $80.4 \%$ of mothers who were not assisted by health workers during childbirth gave breast milk for 0-6 months. Based on these data, besides the place of birth that can affect the success of a mother to provide breast milk to children is health workers such as doctors, midwives and nurses. 
Bivariate analysis was carried out to see the distribution between the dependent variable (breastfeeding) and the independent variable (age, place of residence, education, wealth quintile, work status, place of delivery and birth attendant) and at the same time to determine the variables to be used in the next statistical test. Based on table 3, it is known that the number of women aged 15-29 years who breastfeed children with a duration of 0 - 6 months is $79.1 \%$ and women aged $30-49$ years who breastfeed children with a duration of $0-6$ months are $92.1 \%$. The statistical test results obtained $\mathrm{p} \leq 0.05$, it can be concluded that there is a significant relationship between the age variable and the breastfeeding variable. The result of the Odds ratio (OR) analysis of the age variable was 0.322 , meaning that women aged 15-29 had a 0.322 times greater chance of breastfeeding with a duration of 0-6 months than women aged $30-49$ years. There are $88.9 \%$ of women who live in rural areas breastfeed their children with duration of $0-6$ months. In the variable of residence, the statistical test results obtained by $\mathrm{p} \geq 0.05$, meaning that there is no significant relationship between the variable of residence and the variable of breastfeeding. The OR value obtained from the variable of residence is 0.772 , meaning that women in rural areas have a 0.772 times greater chance

Table 3. Bivariate Analysis Results between Moternal Characteristics and Breastfeeding Behavior, East Nusa Tenggara, 2017

\begin{tabular}{|c|c|c|c|c|c|c|c|c|}
\hline \multirow{3}{*}{ Variable } & \multicolumn{4}{|c|}{ Breastfeeding } & \multirow{2}{*}{\multicolumn{2}{|c|}{ Total }} & \multirow{3}{*}{ OR } & \multirow{3}{*}{ P Value } \\
\hline & \multicolumn{2}{|c|}{$\leq 6$ Months } & \multicolumn{2}{|c|}{$>6$ Months } & & & & \\
\hline & $\mathrm{n}$ & $\%$ & $\mathrm{n}$ & $\%$ & $\mathrm{n}$ & $\%$ & & \\
\hline \multicolumn{9}{|l|}{ Ages } \\
\hline $30-49$ & 399 & 92.1 & 34 & 7.9 & 433 & 100 & 0.322 & 0.000 \\
\hline $15-29$ & 121 & 79.1 & 32 & 20.9 & 153 & 100 & & \\
\hline \multicolumn{9}{|l|}{ Residence } \\
\hline City & 87 & 87.9 & 12 & 12,1 & 99 & 100 & 1.103 & 0.772 \\
\hline Village & 433 & 88.9 & 54 & 11,1 & 487 & 100 & & \\
\hline \multicolumn{9}{|l|}{ Education } \\
\hline Not school, Sekolah Dasar, Junior high school & 462 & 89.7 & 53 & 10.3 & 515 & 100 & 0.466 & 0.019 \\
\hline Senior high school+ & 57 & 80.3 & 14 & 19.7 & 71 & 100 & & \\
\hline \multicolumn{9}{|l|}{ Wealth Quintile } \\
\hline Middle and Top & 23 & 85.2 & 4 & 14.8 & 27 & 100 & 1.394 & 0.550 \\
\hline $\begin{array}{l}\text { Lowest, Medium } \\
\text { and Intermediate }\end{array}$ & 497 & 88.9 & 62 & 11.1 & 559 & 100 & & \\
\hline \multicolumn{9}{|l|}{ Work Status } \\
\hline Not working & 168 & 80.0 & 42 & 20.0 & 210 & 100 & 3.520 & 0.000 \\
\hline Working & 351 & 93.4 & 25 & 6.6 & 376 & 100 & & \\
\hline \multicolumn{9}{|l|}{ Place of birth } \\
\hline Medical Facility & 433 & 89.6 & 50 & 10.4 & 483 & 100 & 0.628 & 0.131 \\
\hline Not a Medical Facility & 87 & 84.5 & 16 & 15.5 & 103 & 100 & & \\
\hline \multicolumn{9}{|l|}{ Place of Birth } \\
\hline Not a Health Officer & 262 & 80.4 & 64 & 19.6 & 326 & 100 & 1.099 & 0,905 \\
\hline Health Officer & 9 & 81.8 & 2 & 18.2 & 11 & 100 & & \\
\hline
\end{tabular}


of breastfeeding for a duration of 0-6 months compared to women living in urban areas. As many as $89.7 \%$ of women who provide breasth milk with a duration of 0-6 months do not go to school, elementary school, junior high school. The results of statistical tests obtained $p \leq 0.05$, it can be concluded that there is a significant relationship between the education variable and the breastfeeding variable. Meanwhile, the OR value on the education variable is 0.466 , which means that women with education who do not attend school, elementary school and junior high school have a 0.466 times greater chance of breastfeeding compared to women who have junior high school and college education. The length of breastfeeding in women with higher education tends to be shorter than in women with low education. And women who live in urban areas are shorter than women from rural areas (Wilopo, 2009).

The duration of breastfeeding for $0-6$ months in women who have the lowest, middle, and middle wealth quintile is $88.9 \%$. The results of statistical tests obtained $\mathrm{p} \geq 0.05$, meaning that there is no significant relationship between the wealth quintile variable and the breastfeeding variable. From the analysis, the OR value on the wealth quintile variable is 1.394 , which means that women with the lowest, middle and middle wealth quintiles have a 1,394 times greater chance of breastfeeding than women who have the upper and upper middle wealth quintiles. Women who belong to a low socioeconomic level, work in the agricultural sector, housewives have a longer breastfeeding habit than women who work in the informal sector, civil servants and office employees (Wilopo, 2009).

The results of the analysis between work status and breast milk giving for 0-6 months showed that women who worked were greater than those who did not work, namely as much as $93.4 \%$. From the results of statistical tests, it was revealed that there was a significant relationship between work status and the provision of breast milk as indicated by the acquisition of $p \leq 0.05$ while the OR value on the variable working status is 3,520 , which means that women who work have a 3.520 times greater chance of breastfeeding than women who do not work. The table above shows that $89.6 \%$ of women who had breastfeeding duration of 0-6 months gave birth to their children in health facilities.

From the results of statistical tests, it was obtained that the value of $p=0.131 p \geq 0.05$ means that there is no significant relationship between the variable place of delivery and the variable of breastfeeding. The analysis also showed that the OR value was 0.628 , meaning that women who gave birth to their children in health facilities had a 3.520 times greater chance of breastfeeding compared to women who gave birth not in health facilities.

The table above also shows that there were $81.8 \%$ of women who were assisted in childbirth. the relationship between the birth attendant variable and the breastfeeding variable was obtained $\mathrm{p} \geq 0.05$, meaning that there was no significant relationship between the childbirth assistant variable and the breastfeeding variable. The result of the OR analysis of the birth attendant variable was 1.099 , which explained that women who were assisted by health workers had a 1.099 times greater chance of breastfeeding with a duration of 0-6 months than women who were not assisted by health workers.

From the results of the statistical analysis above, it is obtained that the independent variable has a significant relationship with the dependent variable, namely the variable age, education and work status. The results of the analysis obtained are slightly different from the results of research conducted in Manipur, India which revealed that residence, education, employment status and parity had a significant effect on breastfeeding practice with a duration of about 20 months, which was below the Indian national figure of 25 months and WHO recommended 24-month rate (Sanajaoba Singh and Sharat Singh, 2011).

UNICEF and WHO recommend breastfeeding alone for the first 6 months, followed by solid food feeding after 6 months of age, continued breastfeeding until the child is 2 years old. Trending data show that the prevalence of exclusive breastfeeding for infants under six months in developing countries 
increased from 33\% in 1995 to $39 \%$ in 2010. Prevalence is increasing in almost all regions of developing countries, with the largest increases seen in West and Central Africa (Cai, Wardlaw and Brown, 2012). In line with that, according to Simondon 2009 in developing countries, women who are less educated breastfeed longer (K.B. Simondon, 2009).

The results of a study on the duration of breastfeeding in Manipur, India, inform that residence, education, employment status and parity have a significant effect on the duration of breastfeeding, which is around 20 months. The duration of breastfeeding is still below the Indian national figure of 25 months and the WHO recommended 24 months (Sanajaoba, Sharat, 2011). Whereas in Uganda people are encouraged to initiate early, exclusive breastfeeding and mothers are advised to give birth in hospital, so they can consult with professionals who can provide advice and help to start breastfeeding (Bbaale, 2014).

The movement for giving breast milk has been very intensively carried out by the government and breastfeeding activists in Indonesia. One form of government concern regarding breast milk is the issuance of a government policy regarding the exclusive breast milk program as outlined in the Government Regulation of the Republic of Indonesia Number 33 of 2012. Giving v to newborns can provide better immunity compared to babies who do not get Breast milk. Breastfeeding for six months after giving birth and supported by eating safe and nutritious amounts of food helps ensure good nutritional status and protects against disease (Xiaodong, et al, 2012). In addition, the longer a woman breastfeeds can affect the interval for giving birth to the next children. Breastfeeding itself has contraceptive effects and plays an important role in spacing children and limiting family size in developing countries (King, 2007).

Based on the 2002/03 IDHS data, the proportion of exclusive breastfeeding in Indonesia for infants aged $<6$ months is $39.5 \%$ and the average for all children who are exclusively breastfed is 3.2 months, while the median length of breastfeeding is 22.3 months (Ministry of Health, 2012). Meanwhile, the data for the 2017 IDHS showed that 52\% of children under 6 months of age received exclusive breastfeeding and the median length of exclusive breastfeeding was 3 months and the median length of breastfeeding was 21.8 months (Central Statistics Agency, National Family Planning Coordinating Board, Ministry of Health, 2019 ). There are 3 main factors related to the practice of breastfeeding, namely the cultural practice (tradition) of breastfeeding, adoption with modern culture such as the use of health services and the influence of the socioeconomic background of the family (Siswanto, 2009).

From the sample of the Indonesian Demographic and Health Survey (IDHS 2017), East Nusa Tenggara (NTT) Province, 2,223 unweighted female samples were collected (the number of survey samples is based on selected households that were completed interview). The number of samples in order to represent the province of East Nusa Tenggara, a proper sample of 2,223 women is equivalent to 882 women, while 626 women are currently married so that the number of women in the weighted sample is the sample in the analysis explanation.

Multivariable results

This analysis aims to determine the most dominant relationship between the independent variables (age, place of residence, education, wealth quintile, work status, place of delivery and birth attendant) and the dependent variable (breastfeeding). From the results of the bivariate analysis, there are four variables that have a $p$ value $<0.25$, namely age, education, work status and place of birth, then these variables can be included in the logistic regression analysis model.

Based on the results of the multivariate model in the table above, variables with a $p$ value $>0.05$ will be excluded and taking into account the Odds Ratio (OR) value. In this modeling stage, the variable of residence is issued.

Based on the table above, the results of the multivariate analysis between the independent and dependent variables show that the variables that have a contribution in influencing breastfeeding with a duration of 0-6 months are age, education and work status. These variables had a significant relationship with the 
Table 4. Analyst Results of the Initial Model of Multivariate Logistic Regression Characteristics of Mothers with Breastfeeding Behavior, East Nusa Tenggara, 2017

\begin{tabular}{lllllllll}
\hline Variable & B & S.E. & Wald & df & Sig. & $\operatorname{Exp}(B)$ & \multicolumn{2}{c}{$95 \%$ C.I.for EXP(B) } \\
\hline Ages & -.763 & .283 & 7.263 & 1 & .007 & .466 & .268 & .812 \\
Education & -1.027 & .368 & 7.811 & 1 & .005 & .358 & .174 & .736 \\
Place of Service & -.386 & .329 & 1.370 & 1 & .242 & .680 & .357 & 1.297 \\
Work Status & 1.238 & .290 & 18.258 & 1 & .000 & 3.449 & 1.955 & 6.086 \\
\hline
\end{tabular}

Table 5. Analyst Results of the Final Model of Multivariate Logistic Regression Characteristics of Mothers with Breastfeeding Behavior, East Nusa Tenggara, 2017

\begin{tabular}{lllllllll}
\hline Variable & B & S.E. & Wald & df & Sig. & $\operatorname{Exp}(B)$ & \multicolumn{2}{c}{$95 \%$ C.I.for EXP(B) } \\
\hline Ages & -.809 & .280 & 8.339 & 1 & .004 & .445 & .257 & .771 \\
Education & -.962 & .363 & 7.043 & 1 & .008 & .382 & .188 & .778 \\
Work stutus & 1.245 & .289 & 18.531 & 1 & .000 & 3.472 & 1.970 & 6.118 \\
\hline
\end{tabular}

duration of breastfeeding $(\mathrm{p}<0.05)$ and the OR values were respectively $0.455,0.382$ and 3.472 . Meanwhile, there was no significant relationship between breastfeeding practices and place of residence, wealth quintile, place of delivery and birth attendants. Women who decide to stop breastfeeding or weaning their babies before the age of 6 months because they feel they produce insufficient breast milk and this is influenced by biopsychosocial factors (Afiyanti and Juliastuti, 2012). Studies conducted in Eastern Indonesia show that higher levels of education and demand for health care services lead to better optimal practices of exclusive breastfeeding. Meanwhile, women who work in the non-traditional sector negatively affect the optimal pattern of giving exclusive breast milk (Bue and Priebe, 2018).

There is a correlation between the breastfeeding approach and one of the contraceptive methods of family planning. The government, through the BKKBN, has developed a program for hormonal and nonhormonal family planning methods aimed at controlling population growth. Natural contraceptive methods that can be used are by means of breastfeeding, in newborns by giving exclusive breastfeeding. Breastfeeding is effective contraception in the first 6 months postpartum only if it is done exclusively and at regular intervals, including at night (King, 2007) where modern contraceptives consist of the female surgery method or female sterilization, the male surgery method or male sterilization, pills, IUDs, birth control injections, contraceptive implants, condoms and the Lactation Amenorrhea Method (LAM). LAM is a type of natural contraception that applies the principle of exclusive breastfeeding for 6 months and as long as a woman has not had her period after giving birth. LAM can be said to be a natural family planning method if it is not combined with other contraceptive methods (Central Statistics Agency, National Family Planning Coordinating Board, Ministry of Health, 2019). WHO states that the effectiveness of using LAM contraception reaches $98 \%$. LAM is a transitional contraceptive method and is most appropriate for women who plan to fully breastfeed for 6 months after giving birth (King, 2007). Public knowledge about MAL is still rare, so the data on users of LAM contraception is very small. According to the 2017 IDHS data, the percentage of currently married women 
using LAM in Indonesia is $0.1 \%$. With the study of the strong decomposition of female infertility factors (calculated from the pattern of breastfeeding and sexual relations) in NTT, there is an opportunity to be considered as a factor that affects efforts to reduce fertility in NTT province.

\section{Conclusion}

It can be concluded that the index of the proportion of marriage $\left(\mathrm{C}_{\mathrm{m}}\right)$ and infertility during breastfeeding $\left(\mathrm{C}_{\mathrm{i}}\right)$, the index of non-contraception $\left(\mathrm{C}_{\mathrm{c}}\right)$, decreased between 2002/03 and 2017. This means that the effect of limiting fertility on marital patterns, infertility during breastfeeding and usage patterns and contraceptive effectiveness of each has increased.

The strength of the fertility-inhibiting effect of infertility patterns during breastfeeding in NTT is the best because it is the strongest compared to other provinces in Indonesia, however the pattern of contraceptive use and effectiveness are still the main determinants of the most influencing fertility in NTT.

Based on the infertility index value during breastfeeding, the fertility rate in marriages without contraception, intentional abortion, and breastfeeding (TF) in NTT in 2002/03 was 10.5 children per married woman. This means that the pattern of breastfeeding has resulted in married women in NTT having TF - TNMFR $=10.5-9.8=0.7$ births less. Whereas in $2017,14.7$ children per married woman, which means that the pattern of breastfeeding has resulted in married women in NTT having TF - TNMFR $=14.7-10.6=4.1$ fewer births .

Breastfeeding behavior in women in NTT province has a strong relationship with the variables of age, education and work status. Policies are needed that can encourage and advocate for the community to provide breast milk during the breastfeeding period to their children, which can be started from early initiation, exclusive breastfeeding and longer. In addition, mothers must be given knowledge and information related to the benefits of breast milk for the growth and development of children.

\section{References:}

Afiyanti, Y. and Juliastuti, D. (2012) 'Exclusive breastfeeding practice in Indonesia', British
Journal of Midwifery, 20(7), pp. 484-491. doi: 10.12968/bjom.2012.20.7.484.

Badan Pusat Statistik, Badan Koordinasi Keluarga Berencana Nasional, Departemen Kesehatan, M. I. (2019) Survei Demografi dan Kesehatan Indonesia 2017, BKKBN. doi: 10.1017/ CBO9781107415324.004.

Bbaale, E. (2014) 'Determinants of early initiation, exclusiveness, and duration of breastfeeding in Uganda', Journal of Health, Population and Nutrition, 32(2), pp. 249-260. doi: 10.3329/ jhpn.v32i2.2619.

Bongaarts, J. (1978) 'A Framework for Analyzing the Proximate Determinants of Fertility', Population and Development Review, 4(1), pp. 105-132.

Bongaarts, J. and Potter, R. G. (1983) Fertility , Biology, and Behavior: An Analysis of The Proximate Determinants. New York: Academic Press, Inc.

Bouchard, T., Blackwell, L., Brown, S., Fehring, R., \& Parenteau-Carreau, S. (2018). Dissociation between Cervical Mucus and Urinary Hormones during the Postpartum Return of Fertility in Breastfeeding Women. The Linacre quarterly, 85(4), 399-411. https:// doi.org/10.1177/0024363918809698

BPS (2018) Provinsi Nusa Tenggara Timur Dalam Angka 2018. BPS Provinsi Nusa Tenggara Timur. Available at: https://ntt.bps.go.id/ publication/download.

Bue, M. C. L. and Priebe, J. (2018) 'Revisiting the socioeconomic determinants of exclusive breastfeeding practices: Evidence from eastern indonesia, Oxford Development Studies, 46(3), pp. 398-410. doi: 10.1080/13600818.2017.1397620.

Cai, X., Wardlaw, T. and Brown, D. W. (2012) 'Global trends in exclusive breastfeeding', International Breastfeeding Journal, 7, pp. 2-6. doi: 10.1186/1746-4358-7-12.

Davis, K. and Blake, J. (1956) 'Social Structure and Fertility: An Analytic Framework', Economic Development and Cultural Change. doi: 10.1086/449714.

Glasier, A., Bhattacharya, S., Evers, H., Gemzell-Danielsson, K., Hardman, S., Heikinheimo, O., La Vecchia, C., Somigliana, E., \& Annual Capri Workshop Group (2019). Contraception after pregnancy. Acta obstetricia et gynecologica Scandinavica, 98(11), 1378-1385. https://doi. org/10.1111/aogs.13627

Harrison, C. L., Brown, W. J., Hayman, M., Moran, L. J., \& Redman, L. M. (2016). The Role of Physical Activity in Preconception, 
Pregnancy and Postpartum Health. Seminars in reproductive medicine, 34(2), e28-e37. https://doi.org/10.1055/s-0036-1583530

K.B. Simondon (2009) Measuring trace immune factors in human milk, Early Breast-feeding Cessation and Infant Mortality in Lowincome Countries: Workshop Summary. doi: 10.1007/978-1-4020-8749-3_24.

Kementrian Kesehatan (2012) Survei Demografi dan Kesehatan Indonesia 2002-2003. Available at: http://demografi.bps.go.id/phpfiletree/sdki/ BahanAjarSDKI2007/Lainnya/Publikasi SDKI 2002-2003/RingkasanSDKI02-03.pdf.

King, J. (2007) 'Contraception and Lactation', Journal of Midwifery and Women's Health, 52(6), pp. 614-620. doi: 10.1016/j.jmwh.2007.08.012.

Lim, A., van Schalkwyk, M., Maani Hessari, N., \& Petticrew, M. P. (2019). Pregnancy, Fertility, Breastfeeding, and Alcohol Consumption: An Analysis of Framing and Completeness of Information Disseminated by Alcohol Industry-Funded Organizations. Journal of studies on alcohol and drugs, 80(5), 524-533. https://doi.org/10.15288/jsad.2019.80.524

Muzayyaroh and Fatimah, L. (2012) 'Hubungan Pemberian ASI Eksklusif dengan Kembalinya Menstruasi pada Ibu Menyusui di Desa Ngumpul , Jogoroto, Jombang, journal. unipdu. Available at: http://journal.unipdu. ac.id:8080/index.php/seminas/article/ view/167/114.
Oyekale, A. S., \& Maselwa, T. C. (2018). Maternal Education, Fertility, and Child Survival in Comoros. International journal of environmental research and public health, 15(12), 2814. https://doi.org/10.3390/ ijerph15122814

Rahmadewi, R. and Asih, L. (2011) 'Tingkat Fertilitas di Provinsi Nusa Tenggara Timur dan Yogyakarta, Kesmas: National Public Health Journal, 6(3), p. 117. doi: 10.21109/ kesmas.v6i3.102.

Rifdi, F. \& Martika, S. (2019) (2019) 'Faktor-Faktor Yang Berhubungan Dengan Penerapan, Maternal Child Health Care Journal. 1(1)., 1(1), pp. 1-9. Available at: file://C:/Users/ MUSANG/Downloads/261-1762-1-PB (2). pdf.

Samosir, O. B. (2019) Dekomposisi fertilitas Indonesia: Analisis berdasarkan hasil SDKI 2017.

Sanajaoba Singh, N. and Sharat Singh, N. (2011) 'Determinants of duration of breastfeeding amongst women in Manipur', Bangladesh Journal of Medical Science, 10(4), pp. 235239. doi: 10.3329/bjms.v10i4.9493.

Wilopo, S. A. (2009) 'Pola, tren, dan perbedaan praktik menyusui di Indonesia: analisis deskriptif peran modernisasi dan budaya tradisional dari data Survei Demografi Kesehatan Indonesia 2007', Jurnal Gizi Klinik Indonesia, p. 42. doi: 10.22146/ijcn.17688. 